\title{
Kebijakan Disiplin Aparatur Sipil Negara di Dinas Pengelolaan Keuangan, Aset dan Pendapatan Kabupaten Minahasa
}

\author{
Elvis Lumingkewas \\ FIS UNIMA \\ Prodi Ilmu Administrasi Negara \\ Tondano, Indonesia \\ elvislumingkewas@unima.ac.id
}

\begin{abstract}
Abstrak - Adapun yang menjadi tujuan ini adalah: (1) Untuk mengetahui, menganalisis dan mendeskripsikan mengenai mempengaruhi Implenetasi Kebijakan Disiplin Aparatur Sipil Negara di Dinas Pengelola Keuangan, Aset dan Pendapatan Kabupaten Minahasa. (2) Untuk mengetahui, menganalisis dan mendeskripsikan faktor-faktor apa yang mempengaruhi mempengaruhi Implenetasi Kebijakan Disiplin Aparatur Sipil Negara di Dinas Pengelola Keuangan, Aset dan Pendapatan Kabupaten Minahasa. Sedangkan, Metode yang digunakan peneliti dalam penelitian ini yaitu metode penelitian kualitatif.
\end{abstract}

Berdasarkan hasil penelitian dan pembahasan yang telah peneliti lakukan terhadap fokus penelitian mengenai Pelaksanaan PP No 53 tahun 2010 tentang Disiplin PNS Dinas Pengelola Keuangan, Aset dan Pendapatan Daerah Kabupaten Minahasa maka diperoleh kesimpulan sebagai berikut: pertama Implenetasi Kebijakan Disiplin Aparatur Sipil Negara ASN di Dinas Pengelola Keuangan, Aset dan Pendapatan Daerah Kabupaten Minahasa diperoleh kesimpulan bahwa kebijakan tersebut tidak dapat berjalan/diimplementasikan dengan baik, Kegagalan Implementasi Kebijakan PP No 53 tahun 2010 tentang Disiplin ASN Dinas Pengelola Keuangan, Aset dan Pendapatan Daerah Kabupaten Minahasa baik dari sisi proses dan hasil yang dicapai secara umum dapat bersumber pada 2 (dua) faktor utamanya itu: (1) Akibat pelaksanaan kebijakan yang kurang baik (bad execution) dan (2) Akibat adanya kondisi lingkungan kebijakan yang kurang mendukung (bad condition). Sedangkan faktor-faktor yang mempengaruhi Implenetasi Kebijakan Disiplin Aparatur Sipil Negara ASN di Dinas Pengelola Keuangan, Aset dan Pendapatan Kabupaten Minahasa yakni: (1) Sosialisasi kebijakan yang kurang. (2) Mentalitas pegawai yang kurang baik. (3) Tidak adanya panutan/contoh tentang disiplin (4) Tidak adanya pemberian sangsi berupa Reward and Punishment yang jelas dan tegas (5) Faktor pilih kasih (6) Tidak ada Job Description yang jelas bagi staf pelaksana sehingga pelaksana hanya menunggu perintah dari atasan dalam bekerja. Adapun yang menjadi saran adalah; (1) Implenetasi Kebijakan Disiplin ASN di Dinas Pengelola Keuangan, Aset dan Pendapatan Daerah Kabupaten Minahasa harus diupayakan dilaksanakan secara maksimal.capaian tujuan organisasi khususnya maupun terhadap kinerja Pegawai Negeri Sipil selaku pelayan masyarakat. (2) Perlunya sosialisasi terhadap Kebijakan PP No 53 tahun 2010 tentang Disiplin PNS baik Dinas Pengelola Keuangan, Aset dan Pendapatan Daerah Kabupaten Minahasa maupun disetiap organisasi pemerintah lainnya. (3) Faktor pimpinan sebagai pelaku kebijakan harus paham terhadap isi kebijakan, mampu menjadi contoh dalam pelaksanaan kebijakan, menerapkan prinsip "reward and punishment" secara tepat, bertindak adil dan bijaksana terhadap pegawai dan mampu mengawasi, membimbing dan 
membagi tugas terhadap pegawai dengan baik.(4) Faktor bawahan sebagai pelaku/pelaksana kebijakan harus paham terhadap isi kebijakan tersebut, memiliki mentalitas yang baik, bersikap kreatif, inisiatif dan bertanggungjawab terhadap pekerjaan yang diberikan kepadanya dan senantiasa disiplin dalam bekerja.

Kata Kunci: Implementasi, kebijakan dan disiplin

\section{PENDAHULUAN}

Keberhasilan suatu organisasi pemerintah dalam memberikan pelayanan yang bermutu bukan saja ditentukan oleh keahlian dan kecakapan dari aparat melainkan juga sangat ditentukan displin para aparat itu sendiri. Bagi aparatur pemerintahan disiplin tersebut mencakup unsur-unsur ketaatan, kesetiaan, kesungguhan dalam menjalankan tugas dan kesanggupan berkorban, dalam arti mengorbankan kepentingan pribadi dan golongannya untuk kepentingan negara dan masyarakat.

Menyadari pentingnya disiplin dari aparat kepemerintahan, maka Pemerintah mengeluarkan Kebijakan berupa Peraturan Pemerintah Nomor 53 Tahun 2010, Tentang Disiplin Pegawai Negeri Sipil di mana di dalamnya antara lain diatur halhal sebagai berikut: kewajiban, larangan, sanksi, tata cara pemeriksaan, tata cara penjatuhan dan penyampaian hukuman disiplin, dan tata cara pengajuan keberatan terhadap hukuman disiplin yang dilakukan.

Dalam PP No. 53 th 2010 jelas disebutkan definisi disiplin serta penegasan sanksi yang diberikan bagi pelanggar disiplin. Disiplin Pegawai Negeri Sipil adalah kesanggupan Pegawai Negeri Sipil untuk menaati kewajiban dan menghindari larangan yang ditentukan dalam peraturan perundang-undangan dan/atau peraturan kedinasan yang apabila tidak ditaati atau dilanggar dijatuhi hukuman disiplin.Selanjutnya disampaikan juga bahwa pelanggaran disiplin adalah setiap ucapan, tulisan, atau perbuatan PNS yang tidak menaati kewajiban dan/atau melanggar larangan ketentuan disiplin PNS, baik yang dilakukan di dalam maupun di luar jam kerja.

Dinas Pengelola Aset, Keuangan dan Pendapatan Kabupaten Minahasa selatan telah berupaya mengimplementasi Kebijakan Tentang Disiplin PNS tersebut, salah satunya dengan melakukan absensi sidik jari, namun pada kenyataanya tetap saja masih ada celah yang dimanfaatkan pegawai untuk bisa meninggalkan pekerjaan yang menjadi tanggung jawabnya. Selain itu juga hampir tidak terlihat tindakan dari atasan dalam upaya menegur ataupun memberikan peringatan bagi pegawai yang melanggar disiplin. Selain itu juga, dalam penelitian awal terkesan bahwa Peraturan Pemerintah no. 53 mengenai Displin PNS hanya diterapkan setengah-setengah hati, dan hanya mengedepankan aspek keterlambatan dan kehadiran saja, sementara pada aspek yang lain seperti kinerja dan lain-lainnya tidak terlalu diperhatikan. Padahal sebagai suatu bentuk kebijakan, peraturan ini seharusnya dilaksanakan secara utuh dan menyeluruh.

Permasalahan-permasalahan tersebut mendorong peneliti untuk melakukan kajian secara ilmiah melalui penelitian dengan judul "Implementasi PP No 53 tahun 2010 tentang Disiplin PNS di Dinas Pengelola Keuangan, Aset dan Pendapatan Kabupaten Minahasa”.

Adapun yang menjadi fokus permasalahan dalam penelitian ini adalah Implementasi PP No 53 tahun 2010 tentng Displin PNS di Dinas Pengelola Keuangan, Aset dan Pendapatan Kabupaten Minahasa.

Rumusan masalah sebagai berikut:

1. Bagaimana Implenetasi Kebijakan Disiplin Aparatur Sipil Negara di Dinas Pengelola Keuangan, Aset dan Pendapatan Kabupaten Minahasa?

2. Faktor-faktor apa yang mempengaruhi Implenetasi Kebijakan Disiplin Aparatur Sipil Negara di Dinas Pengelola Keuangan, Aset dan Pendapatan Kabupaten Minahasa?

Selanjutnya tujuan penelitian ini adalah: 
1. Untuk mengetahui, menganalisis dan mendeskripsikan mengenai mempengaruhi Implenetasi Kebijakan Disiplin Aparatur Sipil Negara di Dinas Pengelola Keuangan, Aset dan Pendapatan Kabupaten Minahasa.

2. Untuk mengetahui, menganalisis dan mendeskripsikan faktor-faktor apa yang mempengaruhi mempengaruhi Implenetasi Kebijakan Disiplin Aparatur Sipil Negara di Dinas Pengelola Keuangan, Aset dan Pendapatan Kabupaten Minahasa

\section{METODE PENELITIAN}

Lokasi penelitian adalah di Dinas Pengelola Keuangan, Aset dan Pendapatan Kabupaten Minahasa

Metode yang digunakan peneliti dalam penelitian ini yaitu metode penelitian kualitatif.

Adapun sumber data utama dalam penelitian ini adalah: Data orang, yakni data-data yang diperoleh melalui wawancara terhadap orangorang yang peneliti nilai memiliki pengetahuan dan informasi yang relevan dengan fokus masalah, dalam hal ini Kepala-kepala bidang, Kepala-kepala seksi serta beberapa pegawai pelaksana dan bukan orang atau data berupa dokumentasi yakni dokumen yang relevan dengan penelitian.

Dokumen baik berupa foto, gambar, tabel, grafik dan sebagainya yang relevan dalam hal ini dokumen di antaranya struktur organisasi, jumlah pegawai, rekapitulasi absen, alat absen sidik jari, dan dokumen-dokumen lain yang mengandung makna-makna Implementasi Kebijakan Peraturan Pemerintah No. 53. Th 2010 tentang Displin PNS, yang ada di Dinas Pengelola Aset, Keuangan dan Pendapatan Kabupaten Minahasa.

Dalam rangka pengumpulan data yang diperlukan penelitian ini, maka peneliti menggunakan teknik dasar sebagai berikut : Observasi, Wawancara dan Dokumentasi.

Dalam penelitian ini menggunakan teknik Interactive Analysis Data dari Miles and
Huberman, yaitu: reduksi data, penyajian data dan verifikasi/penarikan kesimpulan.

Dalam pengujian keabsahan data dalam penelitian ini, peneliti akan menggunakan empat kriteria, yaitu: kredibilitas (kepercayaan data), transferabilitas (nilai keteralihan/dapat diterapkan, dependabilitas (kebergantungan), dan konfirmabilitas (objektivitas data).

\section{PEMBAHASAN HASIL PENELITIAN}

Paparan Data Dinas Pengelola Keuangan, Aset dan Pendapatan Kabupaten Minahasa Selatan

1. Kronologis Terbentuknya Dinas Pengelola Keuangan, Aset dan Pendapatan Kabupaten Minahasa

Badan Pegelola Keuangan Daerah (BPKD) terbentuk pada bulan Oktober 2003, berdasarkan Peraturan Daerah Kabupaten Minahasa No. 17 tahun 2003. Drs. Warouw Karouwan,MM dilantik sebagai Kepala Badan Pengelola Keuangan Daerah Kabupaten Minahasa yang pertama.

Pada tahun 2008 Badan Pengelola Keuangan Daerah diubah menjadi Dinas Pengelola Keuangan, Aset dan Pendapatan sesuai dengan Peraturan Daerah Kabupaten Minahasa Nomor 3 tahun 2008 tentang Organisasi dan Tata Kerja Lembaga Teknis Daerah. Drs. Warouw Karouwan,MM dilantik sebagai Kepala Dinas Pengelola Keuangan, Aset dan Pendapatan yang pertama. Bupati Minahasa kemudian menetapkan Peraturan Bupati Minahasa no. 33 tahun 2008 tentang Penjabaran Tugas dan Fungsi Dinas Pengelola Keuangan, Aset dan Pendapatan. Pada bulan Pebruari 2011 dilantiklah Drs. Ronny Manus, MPM sebagai Kepada Dinas Pengelola Keuangan, Aset dan Pendapatan yang kedua menggantikan Drs. Warouw Karouwan, MM.

2. Visi dan Misi Dinas Pengelola Keuangan, Aset dan Pendapatan Kabupaten Minahasa 
Visi : Terwujudnya Pengelolaan Keuangan Daerah yang Tertib, Tranparan dan Akuntabel.

Misi :

1. Mewujudkan Efisensi dan Efektifitas pengelolaan Sumber Daya Keuangan.

2. Menciptakan APBD Kabupaten Minahasa berbasis Anggaran Kinerja.

3. Meningkatkan Kualitas Sumber Daya Aparatur Pengelola Keuangan Daerah melalui pelayanan Informasi, Sosialisasi, Monitoring dan Evaluasi.

4. Meningkatkan Pendapatan Asli Daerah (PAD) Kabupaten Minahasa.

\section{Tugas dan Fungsi Dinas Pengelola} Keuangan, Aset dan Pendapatan Kabupaten Minahasa

Berdasarkan Peraturan Bupati Minahasa Nomor 33 tahun 2008 Tentang Penjabaran Tugas dan Fungsi Dinas Pengelola Keuangan, Aset dan Pendapatan.

\section{Tugas}

Dinas Pengelola Keuangan, Aset dan Pendapatan mempunyai Tugas melaksanakan penyusunan dan pelaksanaan kebijakan Daerah serta tugas pembantuan di bidang Keuangan, Asset dan Pendapatan yagn menjadi kewenangan Daerah yang diserahkan oleh Pemerintah Pusat kepada Pemerintah Daerah.

\section{Fungsi}

Untuk melaksanakan tugas sebagaimana dimaksud pada pasal 2 Dinas Pengelola Keuangan, Aset dan Pendapatan menyelenggarakan fungsi:

a. Pelaksanaan perencanaan dan perumusan kebijakan teknis dibidang Pengelolah Keuangan, Asset dan Pendapatan Daerah;

b. Pengkoordinasian penyusunan Rancangan APBD dan Rancangan perubahan APBD bersama TPAD;

c. Pelaksanaan pembinaan, pengawasan dan pengendalian anggaran di bidang Pengelolaan Keuangan Daerah; d. Pelaksanaan Pemungutan Pendapatan Daerah yang telah ditetapkan dengan Peraturan Daerah;

e. Pelaksanaan fungsi Bendahara Umum Daerah;

f. Pengkoordinasian integrasi, sinkronisasi dan simplifikasi kegiatan baik dalam lingkungan DInas maupun Instansi atau unit kerja lain yang terkait;

g. Pengkoordinasian, perencanaan dan perumusan kebijakan teknis di bidang Pengelolah Keuangan Daerah;

h. Pelaksanaan pembinaan dan pengawasan pelayanan administrasi ketatausahaan meliputi Perencanaan Program, Keuangan, Kepegawaian dan Umum;

i. Penyusunan Laporan Keuangan daerah dalam rangka pertanggungjawaban pelaksanaan APBD;

j. Pelaksanaan evaluasi kegiatan; dan

k. Penyusunan dan penyampaian laporan kegiatan;

\section{TEMUAN DAN HASIL PENELITIAN}

Berdasarkan penelitian yang dilakukan peneliti terhadap fokus masalah yakni Pelaksanaan PP 53 Tahun 2010 tentang Disiplin PNS di Dinas Pengelola Keuangan Aset dan Pendapatan Kab. Minahasa maka peneliti menemukan hal-hal sebagai berikut:

1. mempengaruhi Implenetasi Kebijakan Disiplin Aparatur Sipil Negara PNS di Dinas Pengelola Keuangan Aset dan Pendapatan Kabupaten Minahasa.

Pelaksanaan mempengaruhi Implenetasi Kebijakan Disiplin Aparatur Sipil Negara di Dinas Pengelola Keuangan Aset dan Pendapatan Kabupaten Minahasa masih belum terlaksana dengan baik. Hal ini terungkap dalam wawancara di mana masih banyak pegawai bahkan pimpinan yang tidak memahami PP 53 tahun 2010 sehingga secara otomatis kebijakan tersebut tidak bisa berjalan 
baik. Tidak mungkin sesuatu peraturan dapat dilaksanakan jika tidak paham akan peraturan tersebut. Dari data-data yang diperoleh bahwa PP 53 Tahun 2010 tentang Disiplin PNS hanya dilihat dari segi disiplin waktu dan disiplin kerja saja padahal dari pasal-pasal yang terkandung di dalamnya banyak terdapat aturan-aturan lain di antaranya mengucapkan sumpah/janji PNS; bekerja dengan jujur, tertib, cermat, dan bersemangat untuk kepentingan negara; masuk kerja dan menaati ketentuan jam kerja; mencapai sasaran kerja pegawai yang ditetapkan; menggunakan dan memelihara barang-barang milik negara dengan sebaikbaiknya; memberikan pelayanan sebaikbaiknya kepada masyarakat; membimbing bawahan dalam melaksanakan tugas; memberikan kesempatan kepada bawahan untuk mengembangkan karier; menaati peraturan kedinasan yang ditetapkan oleh pejabat yang berwenang; memberi atau menyanggupi akan memberi sesuatu kepada siapapun baik secara langsung atau tidak langsung dan dengan dalih apapun untuk diangkat dalam jabatan; menerima hadiah atau suatu pemberian apa saja dari siapapun juga yang berhubungan dengan jabatan dan/atau pekerjaannya; bertindak sewenang-wenang terhadap bawahannya; melakukan suatu tindakan atau tidak melakukan suatu tindakan yang dapat menghalangi atau mempersulit salah satu pihak yang dilayani sehingga mengakibatkan kerugian bagi yang dilayani; menghalangi berjalannya tugas kedinasan; dan berbagai aturan lain yang telah ditetapkan dalam PP No 53 tahun 2010.

Faktor-faktor yang mempengaruhi mempengaruhi Implenetasi Kebijakan Disiplin Aparatur Sipil Negara di Dinas Pengelola Keuangan Aset dan Pendapatan Kab. Minahasa yakni:

- Sosialisasi kebijakan yang kurang mengakibatkan pemahaman ASN terhadap kebijakan dalam hal ini kebijakan PP No. 53 Tahun 2010 tentang Disiplin ASN di Dinas
Pengelola Keuangan Aset dan Pendapatan Kab. Minahasa masih kurang, sehingga tidak dapat dilaksanakan dengan baik.

- Mentalitas pegawai yang kurang baik, dalam hal ini pegawai tidak memiliki kepedulian tentang peraturan yang seharusnya mengikat mereka selaku ASN, dan tidak adanya kesadaran akan tanggung jawabnya terhadap pelaksanaan peraturan, serta tanggung jawab terhadap organisasi di mana dia bekerja. Tidak adanya panutan/contoh tentang disiplin dari pimpinan

Unsur pimpinan dalam hal ini menurut PP No 53 tahun 2010 seharusnya membimbing anakbuahnya untuk melaksanakan tugas dan pekerjaan, namun dalam penelitian ditemui bahwa banyak di antara unsur pimpinan juga melakukan hal yang sama, meninggalkan kantor untuk kepentingan pribadi.

- Tidak adanya pemberian sanksi berupa Reward and Punishment yang jelas dan tegas. Dalam hal ini pemberian sangsi dan hukuman sudah diatur dalam PP No 53 tahun 2010 namun demikian unsur pimpinan tidak melakukan tindakan tegas terhadap pegawai yang melanggar disiplin.

- Faktor Pilih Kasih di mana ada beberapa pegawai yang merasa bahwa mereka memiliki kemampuan dan keahlian yang lebih dibandingkan dengan pegawai lainnya sehingga merasa sangat dibutuhkan di DPKAP dan berbuat seenaknya.

- Tidak ada Job Description yang jelas bagi staf pelaksana sehingga pelaksana hanya menunggu perintah dari atasan dalam bekerja.

Prinsip "Good Governance" begitu populer didengung-dengungkan di dalam upaya reformasi 
sistem pelayanan publik di Indonesia. Hal ini dipicu akibat rendahnya kualitas dan kelambanan pelayanan merupakan gejala yang lazim hadir dalam kinerja birokrasi pelayanan publik di Indonesia yang sampai sekarang ini. Kualitas pelayanan yang buruk masih menjadi keluhan publik pengguna layanan, dan merupakan hal yang "urgent" untuk diadakan pembenahan.

Displin bukan lahir dengan begitu saja, disiplin merupakan hasil bentukan, suatu kebiasaan yang diulang-ulang dan menjadi bagian hidup dari seseorang. Selain dari dalam diri seseorang, lingkungan pun sangat berperan dalam keberhasilan pembentukan disiplin. Hasibuan (2009:194), mengatakan bahwa terdapat beberapa indikator yang mempengaruhi tingkat kedisiplinan karyawan suatu organisasi, antara lain, kapabilitas/ kemampuan, kepemimpinan, balas jasa, keadilan, pengawasan melekat, sanksi/hukuman, ketegasan, dan hubungan kemanusiaan. Indikator-indikator yang dikemukakan oleh Hasibuan dan hal-hal yang diamanatkan oleh kebijakan peraturan pemerintah tersebut benar-benar dilaksanakan, maka penyelengaraan administrasi akan menjadi tertib dan teratur, kelancaran dalam pelayanan, tugastugas kedinasan dapat dilaksanakan secara tepat dan cepat yang pada akhirnya mewujudkan gambaran disiplin yang diharapkan.

Menyadari pentingnya disiplin dari aparat kepemerintahan, maka Pemerintah mengeluarkan Kebijakan berupa Peraturan Pemerintah Nomor 53 Tahun 2010, Tentang Disiplin Pegawai Negeri Sipil di mana di dalamnya antara lain diatur halhal sebagai berikut: kewajiban, larangan, sanksi, tata cara pemeriksaan, tata cara penjatuhan dan penyampaian hukuman disiplin, dan tata cara pengajuan keberatan terhadap hukuman disiplin yang dilakukan.

Dalam PP No. 53 th 2010 jelas disebutkan definisi disiplin serta penegasan sanksi yang diberikan bagi pelanggar disiplin. Disiplin Pegawai Negeri Sipil adalah kesanggupan Pegawai Negeri Sipil untuk menaati kewajiban dan menghindari larangan yang ditentukan dalam peraturan perundang-undangan dan/atau peraturan kedinasan yang apabila tidak ditaati atau dilanggar dijatuhi hukuman disiplin.Selanjutnya disampaikan juga bahwa pelanggaran disiplin adalah setiap ucapan, tulisan, atau perbuatan PNS yang tidak menaati kewajiban dan/atau melanggar larangan ketentuan disiplin PNS, baik yang dilakukan di dalam maupun di luar jam kerja.

\section{Pelaksanaan PP No 53 tahun 2010 tentang} Disiplin PNS di Dinas Pengelola Keuangan, Aset dan Pendapatan Kabupaten Minahasa.

Menurut Thomas R. Dye, kebijakan publik adalah studi tentang "apa yang dilakukan pemerintah, dan mengapa pemerintah mengambil tindakan tersebut, dan apa akibat dari tindakan tersebut" (Parsons, 2001).

Kebijakan PP No 53 tahun 2010 tentang Disiplin PNS di Dinas Pengelola Keuangan, Aset dan Pendapatan Kabupaten Minahasa digolongkan dalam kebijakan berbicara mengenai apa yang dilakukan pemerintah, mengapa pemerintah melakukannya dan apa akibat dari tindakan tersebut. Pada bagian awal telah dijelaskan apa yang dilakukan pemerintah dalam hal ini untuk meningkatkan pelayanan publik untuk mencapai Good Governance, dengan berbagai permasalahan yang ada di seputar Pegawai Negeri Sipil selaku aparat pemerintah pemberi pelayanan. Yakni di antaranya kinerja yang kurang baik, diakibatkan disiplin Pegawai Negeri Sipil yang kurang baik, untuk itu pemerintah merasa perlu membuat Kebijakan PP No 53 tahun 2010 tentang Disiplin PNS agar supaya pegawai negeri sipil lebih disiplin dalam bekerja.

Namun demikian sebuah kebijakan hanya akan sekedar berupa impian atau rencana bagus yang tersimpan rapi dalam arsip, 
apabila tidak ada realisasi dari kebijakan tersebut. Realisasi kebijakan dalam hal ini disebut sebagai implementasi kebijakan. Oleh karena itu dalam studi kebijakan publik tidak dapat mengabaikan begitu saja tahapan implementasi dari sebuah proses kebijakan.

Dengan demikian, tiga jenis tahapan kegiatan analisis kebijakan tersebut saling berhubungan satu dengan yang lain. Kebijakan pada tahap perencanaan ini meliputi berbagai kegiatan yang terkait dengan perencanaan. Dalam hal ini Kebijakan PP No 53 tahun 2010 tentang Disiplin PNS sudah melewati tahap perencanaan di mana sudah dibuat/dike luarkan dalam bentuk kebijakan Pemerintah sejak oktober tahun 2010, sehingga bisa dikatakan sudah hampir setahun kebijakan ini melalui tahap implementasi. Namun demikian jika dilihat secara global di instansi-instansi pemerintah kebijakan ini belum terimplementasikan dengan baik.

Berdasarkan penelitian yang dilakukan di lokasi penelitian yakni Dinas Pengelola Keuangan, Aset dan Pendapatan Daerah mengenai Kebijakan PP No 53 tahun 2010 ctentang Disiplin PNS dapat dilihat bahwa kebijakan tersebut tidak dapat berjalan dengan baik, hal ini mengindikasikan bahwa kebijakannya sendiri sudah cukup baik karena memiliki tujuan dan perencanaan yang baik namun pelaksanaannya yang jelek atau berada pada domain (wilayah) pelakasanaan yang jelek (bad execution) menurut Abdul Wahab dalam Lumingkewas (2006:117).

Selanjutnya masih menurut menurut Abdul Wahab dalam Budi Wiyono (2005:26) kegagalan implementasi kebijakan baik dari sisi proses dan hasil yang dicapai secara umum dapat bersumber pada 3 (tiga) faktor utamanya itu:
(1) Akibat kondisi isi kebijakan (content of policy) kurang terumuskan dengan baik (bad policy);

(2) Akibat pelaksanaan kebijakan yang kurang baik (bad execution),

(3) Akibat adanya kondisi lingkungan kebijakan yang kurang mendukung (bad condition).

Berdasarkan pendapat tersebut dapat dilihat bahwa penyebab gagalnya implementasi kebijakan PP No 53 tentang Disiplin PNS di Dinas Pengelola Keuangan, Aset dan Pendapatan Kabupaten Minahasa mencakup atau bersumber dari dua hal tersebut di atas yakni (2) Akibat pelaksanaan kebijakan yang kurang baik (bad execution), dan (3) Akibat adanya kondisi lingkungan kebijakan yang kurang mendukung (bad condition). Sedangkan untuk point pertama yakni (1) Akibat kondisi isi kebijakan (content of policy) kurang terumuskan dengan baik (bad policy); dalam hal ini rumusan kebijakan yang terkandung dalam PP No 53 tengan Disiplin PNS sudah mengandung unsur kejelasan, dan mudah dimengerti, hanya saja dari data-data yang diperoleh bahwa PP 53 Tahun 2010 tentang Disiplin PNS, karena kurangnya sosialisasi maka pemahaman terhadap peraturan ini menjadi kabur dan tidak jelas. Peraturan pemerintah ini hanya dilihat dari segi disiplin waktu dan disiplin kerja saja padahal dari pasal-pasal yang terkandung di dalamnya banyak terdapat aturan-aturan lain di antaranya mengucapkan sumpah/janji PNS; bekerja dengan jujur, tertib, cermat, dan bersemangat untuk kepentingan negara;masuk kerja dan menaati ketentuan jam kerja; mencapai sasaran kerja pegawai yang ditetapkan; menggunakan dan memelihara barang-barang milik negara dengan sebaikbaiknya; memberikan pelayanan sebaikbaiknya kepada masyarakat; membimbingbawahan dalam melaksanakan tugas; memberikan kesempatan kepada bawahan untuk mengembangkan karier; 
menaati peraturan kedinasan yang ditetapkan oleh pejabat yang berwenang; memberi atau menyanggupi akan memberi sesuatu kepada siapapun baik secara langsung atau tidak langsung dan dengan dalih apapun untuk diangkat dalam jabatan; menerima hadiah atau suatu pemberian apa saja dari siapapun juga yang berhubungan dengan jabatan dan/atau pekerjaannya; bertindak sewenang-wenang terhadap bawahannya; melakukan suatu tindakan atau tidak melakukan suatu tindakan yang dapat menghalangi atau mempersulit salah satu pihak yang dilayani sehingga mengakibatkan kerugian bagi yang dilayani; menghalangi berjalannya tugas kedinasan; dan berbagai aturan lain yang telah ditetapkan dalam PP No 53 tahun 2010. Begitu banyaknya aturan yang ditetapkan dalam pasal-pasal yang ada di PP No 53 tahun 2010, namun peraturan tersebut hanya dipandang secara sempit yakni hanya dari segi kehadiran, tepat waktu, dan menjalankan tugas sesuai dengan sasaran dan tepat waktu.

Faktor kegagalan implementasi kebijakan PP No 53 tahun 2010 tentang disiplin ASN ini bersumber pada Akibat pelaksanaan kebijakan yang kurang baik (bad execution), di mana dalam hal ini kurangnya sosialisasi seperti yang sudah disebutkan di atas, dan kurang tegasnya atasan dalam menjalankan peraturan tersebut. Faktor utama lainnya adalah akibat adanya kondisi lingkungan kebijakan yang kurang mendukung (bad condition). Dalam hal ini menyangkut perilaku pimpinan yang tidak menjadi contoh mentalitas pegawai yang kurang baik serta budaya yang kurang baik yang berkembang dalam organisasi.

Bagaimana peran pimpinan dan bawahan dalam hal ini Pegawai Negeri Sipil selaku pelaksana sangat memegang peranan penting dalam keberhasilan kebijakan publik hal ini sesuai dengan pendapat yang diutarakan Dunn (2000) bahwa pada prospektif kebijakan publik ada tiga elemen dasar dalam sistem kebijakan yang saling pengaruh satu dengan yang lain yakni : (1) Pelaku kebijakan, (2) Kebijakan publik, dan (3) Lingkungan kebijakan. Kegagalan implementasi kebijakan tidak sepenuhnya menjadi tanggungjawab Dinas Pengelola Keuangan, Aset dan Pendapatan Kabupaten Minahasa tetapi juga menjadi tanggungjawab seluruh Pegawai Negeri Sipil yang ada di dalamnya. Seharusnya sebagai suatu kebijakan yang sifatnya mengikat sebagai seorang Pegawai Negeri Sipil yang digaji oleh rakyat melalui pemerintah sepatutnyalah melaksanakan kebijakan tersebut. Jika tidak bisa melaksanakan/mengimplementasikan

kebijakan tersebut, sepatutnyalah malu disebut sebagai Pegawai Negeri Sipil dan menerima gaji dari negara.

2. Faktor-faktor yang mempengaruhi Pelaksanaan PP No 53 tahun 2010 tentang Disiplin PNS di Dinas Pengelola Keuangan, Aset dan Pendapatan Kabupaten Minahasa.

Dalam rangka menegakkan disiplin kerja diperlukan dan selalu diharapkan adanya peraturan yang harus ditaati oleh aparat. Untuk menilai tingkat kedisiplinan kerja dikalangan aparat, menurut pendapat Kuncorohadi (2000:42) dapat dilihat dari hal-hal sebagai berikut:

1). Adanya kesadaran dari masing-masing individu atau aparat bahwa mereka mengejar tujuan atau kepentingan bersama dan bukan kepentingan individu.

2). Adanya kesadaran bahwa mereka itu dibawa satu pimpinan tertentu.

3). Adanya kesadaran dan saling percaya kepada masing-masing aparat secara timbal balik.

Adanya kesadaran tersebut di atas sangat dipengaruhi oleh mentalitas pegawai. Dalam penelitian ditemukan bahwa mentalitas pegawai yang kurang baik, dalam hal ini pegawai tidak memiliki kepedulian tentang peraturan yang seharusnya mengikat mereka selaku PNS, dan tidak adanya kesadaran akan tanggung jawabnya 
terhadap pelaksanaan peraturan, serta tanggung jawab terhadap organisasi di mana dia bekerja. Mentalitas pegawai yang kurang baik tercermin dari perilaku mereka yang tidak memanfaatkan celah-celah yang peraturan yang ada, contohnya dalam absensi sidik jari, ditemukan banyak di antara pegawai yang datang pagi-pagi sekali, belum berpakaian seragam, melakukan absensi atau datang dengan seragam mengambil absen dan ke luar kantor dengan berbagai macam alasan yang merupakan kepentingan pribadi, kemudian pada sore hari kembali untuk absen sidik jari lagi pada saat apel sore, menjelang pulang. Pekerjaan terbengkalai, dan tidak diselesaikan sehingga saling menunggu satu dengan yang lain, berakhir pada tidak selesainya tugas tepat waktu.

Menurut Dunn (2000) bahwa pada prospektif kebijakan publik ada tiga elemen dasar dalam sistem kebijakan yang saling pengaruh satu dengan yang lain yakni : (1) Pelaku kebijakan, (2) Kebijakan publik, dan (3) Lingkungan kebijakan. Dalam hal ini selaku pelaku kebijakan yakni seluruh Pegawai Negeri Sipil khususnya di Dinas Pengelola Keuangan Aset dan Pendapatan Kabupaten Minahasa, dalam hal ini tidak memiliki disiplin diri yang baik maka tentu saja kebijakan tersebut tidak bisa terlaksana.

Dari hasil penelitian yang dilakukan ternyata bahwa tidak adanya panutan/contoh tentang disiplin dari pimpinan. Di mana unsur pimpinan dalam hal ini menurut PP No 53 tahun 2010 seharusnya membimbing anakbuahnya untuk melaksanakan tugas dan pekerjaan, namun ternyata banyak di antara unsur pimpinan juga melakukan hal yang sama, meninggalkan kantor untuk kepentingan pribadi.

Pengawasan juga berkaitan dengan pemberian sangsi baik itu reward dan punishment. Tidak adanya pemberian sanksi Reward and Punishment yang jelas dan tegas bagi pegawai teladan dalam hal disiplin dan sangsi atau hukuman yang jelas bagi yang melanggar disiplin. Dalam hal ini pemberian sangsi dan hukuman sudah diatur dalam PP No 53 tahun 2010 namun demikian unsur pimpinan tidak melakukan tindakan tegas terhadap pegawai yang melanggar disiplin. Faktor Pilih Kasih di mana ada beberapa pegawai yang merasa bahwa mereka memiliki kemampuan dan keahlian yang lebih dibandingkan dengan pegawai lainnya sehingga merasa sangat dibutuhkan di DPKAP dan berbuat seenaknya. Tapi juga ada perlakuan dari atasan yang mengistimewakan mereka sehingga terkesan pilih kasih.

Tidak ada Job Description yang jelas bagi staf pelaksana sehingga pelaksana hanya menunggu perintah dari atasan dalam bekerja, jika pimpinan tidak memberikan pekerjaan, mereka tidak bekerja. Jadi seringkali alasan tidak ada pekerjaan menjadi alasan para pegawai untuk ke luar kantor mengurus kepentingan mereka pribadi, dari pada di kantor tidak bekerja.

Berbagai bentuk penyimpangan ini merugikan terhadap organisasi langsung atau tidak langsung. Hal-hal tersebut menjadi penghambat dalam mengimplementasi PP No 53 tahun 2010 di Dinas Pengelola Keuangan, Aset dan Pendapatan Kabupaten Minahasa. Dalam usaha mendisiplinkan kerja ada beberapa faktor yang perlu diperhatikan, yaitu :

1). Pembagian tugas dan pekerjaan telah dibuat lengkap dan dapat diketahui dengan sadar oleh para pekerja.

2). Adanya petunjuk kerja yang singkat, sederhana tetapi lengkap.

3). Kesadaran setiap pekerja terhadap tugas atau pekerjaan yang menjadi tanggungjawabnya.

4). Perlakuan adil terhadap setiap penyimpangan oleh manajemen.

5). Adanya keinsyafan pada pekerja bahwa akibat kecerobohan atau kelalaiannya dapat merugikan organisasi dan dirinya serta ada kemungkinan membahayakan orang lain (Lateiner dan Levine, 2001:151). 


\section{KESIMPULAN DAN SARAN}

\section{KESIMPULAN}

Berdasarkan hasil penelitian dan pembahasan yang telah peneliti lakukan terhadap fokus penelitian mengenai Pelaksanaan PP No 53 tahun 2010 tentang Disiplin PNS Dinas Pengelola Keuangan, Aset dan Pendapatan Daerah Kabupaten Minahasa maka diperoleh kesimpulan sebagai berikut:

1. Implenetasi Kebijakan Disiplin Aparatur Sipil Negara ASN di Dinas Pengelola Keuangan, Aset dan Pendapatan Daerah Kabupaten Minahasa maka diperoleh kesimpulan sebagai berikut kebijakan tersebut tidak dapat berjalan/diimplementasikan dengan baik, Kendati dalam hal ini kebijakannya sendiri sudah cukup baik karena memiliki tujuan dan perencanaan yang baik namun pelaksanaannya yang jelek atau berada pada domain (wilayah) pelakasanaan yang jelek (bad execution). Kegagalan Implementasi Kebijakan PP No 53 tahun 2010 tentang Disiplin ASN Dinas Pengelola Keuangan, Aset dan Pendapatan Daerah Kabupaten Minahasa baik dari sisi proses dan hasil yang dicapai secara umum dapat bersumber pada 2 (dua) faktor utamanya itu: (1) Akibat pelaksanaan kebijakan yang kurang baik (bad execution) dan (2) Akibat adanya kondisi lingkungan kebijakan yang kurang mendukung (bad condition). Dalam hal ini pelaksanaan yang kurang baik dari pelaku kebijakan yakni PNS tersebut dan lingkungan kebijakan yang masih tetap mempertimbangkan budaya-budaya toleransi dan kasihan serta faktor pilih kasih serta mempertahankan budaya tidak disiplin.

2. Faktor-faktor yang mempengaruhi Implenetasi Kebijakan Disiplin Aparatur Sipil Negara ASN di Dinas Pengelola Keuangan, Aset dan Pendapatan Kabupaten Minahasa yakni: (1) Sosialisasi kebijakan yang kurang mengakibatkan pemahaman PNS terhadap kebijakan dalam hal ini kebijakan PP No. 53 Tahun 2010 tentang Disiplin PNS di Dinas
Pengelola Keuangan Aset dan Pendapatan Kab. Minahasa masih kurang. Ketidakpahaman ini bukan saja pada tingkat bawahan tetapi juga pada unsur pimpinan. (2) Mentalitas pegawai yang kurang baik, dalam hal ini pegawai tidak memiliki kepedulian tentang peraturan yang seharusnya mengikat mereka selaku PNS, dan tidak adanya kesadaran akan tanggung jawabnya terhadap pelaksanaan peraturan, serta tanggung jawab terhadap organisasi di mana dia bekerja. Mentalitas pegawai yang kurang baik tercermin dari perilaku mereka yang tidak memanfaatkan celah-celah yang peraturan yang ada, contohnya dalam absensi sidik jari, ditemukan banyak di antara pegawai yang datang pagi-pagi sekali, belum berpakaian seragam, melakukan absensi atau datang dengan seragam mengambil absen dan ke luar kantor dengan berbagai macam alasan yang merupakan kepentingan pribadi, kemudian pada sore hari kembali untuk absen sidik jari lagi pada saat apel sore, menjelang pulang. Pekerjaan terbengkalai, dan tidak diselesaikan sehingga saling menunggu satu dengan yang lain, berakhir pada tidak selesainya tugas tepat waktu. Faktor budaya yang kurang baik yang merasa bangga apabila melakukan pelanggaran dan tidak dikenai sanksi. Akibatnya budaya indisipliner menjadi semakin berkembang. Karena merasa tidak ada tindakan dari atasan. Hal ini Mengakibatkan mentalitas para pegawai semakin buruk, budaya tidak disiplin akhirnya bukan saja menjadi budaya dalam pribadi masing-masing pegawai, melainkan berkembang menjadi budaya organisasi. (3) Tidak adanya panutan/contoh tentang disiplin dari pimpinan Unsur pimpinan dalam hal ini menurut PP No 53 tahun 2010 seharusnya membimbing anakbuahnya untuk melaksanakan tugas dan pekerjaan, namun dalam penelitian ditemui bahwa banyak di antara unsur pimpinan juga melakukan hal yang sama, meninggalkan kantor untuk 
kepentingan pribadi; (4) Tidak adanya pemberian sangsi berupa Reward and Punishment yang jelas dan tegas. Dalam hal ini pemberian sangsi dan hukuman sudah diatur dalam PP No 53 tahun 2010 namun demikian unsur pimpinan tidak melakukan tindakan tegas terhadap pegawai yang melanggar disiplin. Tidak adanya pemberian penghargaan terhadap pegawai yang rajin dan menyelesaikan tugasnya dengan baik. (5) Faktor pilih kasih di mana ada pembedaan dalam perlakukan atasan terhadap bawahan, baik karena kedekatan hubungan maupun karena jenis pekerjaan yang dibebankan kepadanya; (6) Tidak ada Job Description yang jelas bagi staf pelaksana sehingga pelaksana hanya menunggu perintah dari atasan dalam bekerja.

\section{SARAN}

1. Implenetasi Kebijakan Disiplin Aparatur Sipil Negara ASN di Dinas Pengelola Keuangan, Aset dan Pendapatan Daerah Kabupaten Minahasa harus diupayakan dilaksanakan secara maksimal, karena jika tidak diimplementasikan dengan baik akan berakibat buruk terhadap pencapaian tujuan organisasi khususnya maupun terhadap kinerja Pegawai Negeri Sipil selaku pelayan masyarakat.

2. Perlunya sosialisasi terhadap Kebijakan PP No 53 tahun 2010 tentang Disiplin PNS baik Dinas Pengelola Keuangan, Aset dan Pendapatan Daerah Kabupaten Minahasa maupun disetiap organisasi pemerintah lainnya.

3. Faktor pimpinan sebagai pelaku kebijakan harus paham terhadap isi kebijakan, mampu menjadi contoh dalam pelaksanaan kebijakan, menerapkan prinsip "reward and punishment" secara tepat, bertindak adil dan bijaksana terhadap pegawai dan mampu mengawasi, membimbing dan membagi tugas terhadap pegawai dengan baik.

4. Faktor bawahan sebagai pelaku/pelaksana kebijakan harus paham terhadap isi kebijakan tersebut, memiliki mentalitas yang baik, bersikap kreatif, inisiatif dan bertanggungjawab terhadap pekerjaan yang diberikan kepadanya dan senantiasa disiplin dalam bekerja.

\section{REFERENSI}

[1] Agustino, L. 2006. Dasar-Dasar Kebijakan Publik, Alfabeta, Bandung.

[2] Atmosudirjo, P. 2000. Dasar-dasar Manajemen, Haji Mas Agung, Jakarta.

[3] Hasibuan, 2000. Pengantar Manajemen dan Office Manajemen, Ghalia Indonesia, Jakarta.

[4] Islamy, I. M. dkk. 2001. Metode Penelitian Administrasi. Fakultas Ilmu Administrasi. Universitas Brawijaya. Malang.

[5] , 2001. Policy Analysis. Program Pascasarjana. Universitas Brawijaya. Malang.

[6] Kuncorohadi, 2000. Beberapa Aspek Kepegawaian. Fisip, Undip, Semarang.

[7] Laitener, A. Dan I.E. Levine, 2001. Teknik memimpin Pegawai dan Pekerja, Jaya Sakti, Terjemahan Jakarta,

[8] Lumingkewas, L.A. 2006. Reformasi Birokrasi dalam Perpektif Otonomi Daerah, Program Pascasarjana Universitas Negeri Manado.

[9] 2006. Kebijakan Publik, Wineka Media Malang.

[10] Marat, 2001. Sikap manusia Perubahan serta Pengukurannya, Obor Indonesia, Jakarta.

[11] Moenir, H.A.S., 2003. Pengembangan Sumber Daya Manusia, PT. Pustaka Press, Jakarta.

[12] Mubyarto. 1998, Etos Kerja dan Kohesi Sosial, P.T. Adtya Media, Yogyakarta.

[13] Munandar. 2008, Disiplin Kiat Menuju Sukses, P.T. Gramedia, Jakarta.

[14] Parsons, W. I. 2007. Public Policy, An Introduction to The Theory and Practice of Policy Analysis, Edward Elgor Cheltenham UK, Lyme, US.

[15] Putra, S. 2001. Membina Sikap Mental Wirausaha, Gunung Jati Jakarta.

[16] Peraturan Pemerintah Nomor 53 Tahun 2010 tentang Disiplin Pegawai Negeri Sipil.

[17] Pusdiklat, Spimnas. 2001. Kajian Kebijakan Publik. Lembaga Administrasi Republik Indonesia. Jakarta.

[18] Robbins, S.P. 2006, Perilaku Organisasi, P.T. Prenhalindo, Terjemahan, Jakarta.

[19] Senge, P.M. 2002, The Fifth Discipline, Inter Aksara, Terjemahan, Batam.

[20] Soegeng. 1994, Disiplin Kiat Menuju Sukses, PT. Pradnya Paramita, Jakarta

[21] Soemarno, D. 1995, Gerakan Disiplin Nasional, Balai Pustaka, Jakarta. 
Jurnal Kajian Kebijakan dan Ilmu Adminstrasi Negara (Jurnal ADMINISTRO)

http://ejournal.unima.ac.id/index.php/administro 